\title{
The Development of School Based Curriculum in Ghana Schools: The Effects on Students
}

\author{
Stephen Nyame \\ College of Education, Liaocheng University, No. 1 Hunan Street, Liaocheng, Shandong China
}

\begin{abstract}
The concept of school based curriculum development has been of keen interest through my profession as a teacher. Since end of school test is based on the central curriculum, teachers and stakeholders usually pay less attention to other curriculum types, like school-based curriculum development (SBCD). Can students achieve something out of SBCD? Does it have any positive effect on students learning? With different learning needs of learners and dynamism in education. I argue that SBCD should be introduced in Ghana schools. Through literature mining, mine and colleague's experience, I discuss the following as to why SCBD should be introduced into Ghana schools: First to meet the needs and interests of students and the school community; Second, to insert school learning into local contexts, knowledge, and resources, and meet local and national aspirations; Thirdly, respond to new social issues and technology in education.

Keywords: School based curriculum development (SBCD), central curriculum, student learning, Student interest, community interest, social issues, local learning context.

DOI: $10.7176 / \mathrm{JEP} / 11-2-14$

Publication date: January $31^{\text {st }} 2020$

\section{Introduction}

The motive of parents sending their wards to school, the development of the central curriculum itself and all the hustle and bustle teachers and school administrators go through is for students to learn and become an effective member of society. A curriculum content must be open, reflecting the new requirements or needs of the society. Progressives see society as needing improvement and the schools as serving the function of helping students become thinking citizens who can contribute to creating a more just society. John Dewey, the leading progressive educator of the century, wrote that "education is the fundamental method of social progress and reform. However, the central curriculum as its name implies is rigid and sometimes do not provide equity for all learners because of different needs and interest of learners and their society, students learning context and resources and new social and technological issues. Therefore the introduction of SBCD in Ghana schools will help cater for all, irrespective of students needs and background and be effective on their learning.
\end{abstract}

\section{What Is School-Based Curriculum Development?}

There is no definite definition for SBCD. The term is used in literature at different times as a slogan, as an educational philosophy, or as a method or technique (Marsh, Day, Hannay, \& McCutcheon, 1990). As a slogan, SBCD:

...conjures up action at the local level, it connotes participation, grass-roots control, and many other attributes which are held to be near and dear to the general public (Marsh et al., 1990, p. 47).

Meanwhile, authors like Skilbeck (1984, cited in Marsh et al., 1990), elucidate SBCD as an educational philosophy. Skilbeck presents SBCD as ideally internal and organic to the institution, and his descriptions emphasis aspects such as shared decision making between teachers and students. Bezzina (1991) identifies collaboration among school staff as a defining feature of SBCD:

SBCD is a collaborative effort which should not be confused with the individual efforts of teachers or administrators operating outside the boundaries of a collaboratively accepted framework (Bezzina, 1991, p. 40).

School-based curriculum development does not necessarily entail the creation of entirely new curricula within schools (Brady, 1992; Marsh et al., 1990). For example, Bezzina (1991) suggests that SBCD can involve at least three kinds of activity: creating new curricula; adapting existing curricula; and even adopting an existing curriculum unchanged. For Bezzina, the latter still constitutes SBCD, as long as it represents a collaborative choice among staff. Views about what form(s) of SBCD are most desirable vary, and personal and national differences are evident in the literature. For example, Sabar et al. noted that: ... while the English with their supposed tradition of autonomy see SBCD as being about whole school curriculum planning, in Israel SBCD is about planning part of a school curriculum in relation to one or more school subjects (Sabar, Rudduck, \& Reid, 1987, p. 2).

\section{Why School Based Curriculum Development Should Be Introduced Into Ghana Schools.}

To press on the fact that SBCD could be effective on student learning now or in the future, it is necessary to consider why Ghana schools could or should engage in SBCD. Below, I outline three positive effect SBCD can have on Ghanaian students. Drawing from recent literature about education, curriculum, and the future directions 
of schooling, I argue that SBCD can provides a mechanism for Ghana schools to: (1) better meet the needs and interests of students and the school community; (2) insert school learning in local contexts, knowledge, and resources, to meet local and national aspirations; and (3) responding to new issues and technology in education.

1. Meet the needs and interests of students and the school community

To foster students learning, it is appropriate to meet particular needs and interests of students and the school community. The national curriculum and the ministry of education support this statement. However, the standards set do not speak as such. Central Curriculum designers often reference children and situations in the urban centers in curriculum development with less or no consideration for rural areas. With the development of a quality SBC, this situation can be catered for.

In SBCD teachers and school administrators can consult the community to know their interest, needs, and views. Research suggest that parents support the curriculum more when they are consulted for its design. Involving parents and the community in developing the school curriculum clearly poses challenges for schools, as it appears further attention and discussion about the involvement of parents and communities is needed within the Ghana education community, particularly regarding questions of "what", "why", and "how".

What about student involvement in curriculum development?

According Marzano (2003), students learn better and observe rules and procedures when they are involved in the design and implementation. With the curriculum we view as something that is designed for students we can't say, it should be by the learners or with the learners. (Brooker \& Macdonald, 1999; Mac an Ghaill, 1992) both raise questions about the degree to which students' views, opinions, and ideas feature in school curriculum decision making. Brooker and MacDonald (1999) argue that traditional authority structures in schools have "systematically silenced" students' voices in curriculum making, and that even when students' views and opinions are sought, the focus is often on finding out how students view their learning programme, rather than how they have contributed (or might contribute) to the construction of those programme. However, the idea of negotiation or co-development of curriculum with students has been explored elsewhere, particularly with respect to the notion of "curriculum integration" (see Boomer, Lester, Onore, \& Cook, 1992; Fraser, 2000).

.......Mr Kojo Nkrumah a headmaster at Aprapraso D/A school, Ghana, realized an increase in students' interest in Integrated Science after discussing and engaging students in the right farming system for his Rubber Plantation.

...... Nicholas Gemegah, Aponsaso, D/A school, worries no more about lighting for his room after he sought students' opinion on the local material to be used as the casing for an electrical circuit. Students flooded the school the following week with their circuit built into carved dried palm branches.

2. Insert school learning in local contexts, knowledge, and resources.

Developing SBC in Ghana is will enable schools to insert students' learning experiences in local contexts, knowledge, and resources. In order to "teach to the life of the child" as suggested by neuro cognitive scientist Dr. Fritz Mengert, you have to know about the life they are living (http://www.teacher-support-force.com/learningcontext.html). One of the reasons children have trouble with comprehension is that passages are often completely out of their context. Arguably, many Ghana schools already incorporate local contexts knowledge and resources into their teaching to varying degrees.

As a science teacher in rural "Amponsaso D/A school in the Mpohor Wassa East District of the Western Region of Ghana". The best practical approach in teaching fishing was the use of hook and line and fish traps since they have no use for fishing nets as a result of the the width and depth of the water bodies in their community.

The use of local contexts, knowledge, and resources in the school curriculum clearly has connections to the idea described above, that SBCD can allow schools to better meet the needs and interests of schools and communities. There is also a deeper philosophical rationale for embedding school learning in local contexts. Gruenewald (2003) calls this "place-conscious education". Gruenewald's use of the word "place" connotes much more than simply a spatial area or location. "Places" have perceptual, sociological, ideological, political, and ecological dimensions, and "places" are as much a product of human decisions as they are a physical point in time and space. Gruenewald argues that the current education system neglects and obscures our relationship with places: That is, schooling often distracts our attention from, and distorts our response to, the actual contexts of our own lives (places) (Gruenewald, 2003, p. 621). A shift towards place-conscious education has massive implications on the way we think about the purpose of education and schooling. Place-conscious education resonates with the notion that the ultimate purpose of schools is the production of the kind of people we need as members of our community that is, people who will sustain, transform, or create the kinds of "places" we want our world to comprise, at the local, regional, national, and global level: Recognizing that places are what people make of them, that people are place makers and that places are a primary artifact of human culture, suggests a more active role for schools in the study, care, and creation of places. Schools must provide opportunities for students to participate meaningfully in the process of place-making, that is, in the process of shaping what our places will become (Gruenewald, $2003, \mathrm{p}$. 627). Supporting students to "participate meaningfully in the process of place-making" implies a need for school learning to have a visible and meaningful connection to local (as well as national and international) contexts, 
knowledges, and resources - that is, to the "place" in which students live (and learn).

3. Responding to new social issues and technology in education

A third reason for SBCD is to enable Ghana schools to adapt their curriculum in response to new social issues or technologies for teaching and learning. Two potent areas of thought which should be influencing school curricula are: the introduction of new technologies that have the potential to enhance or transform teaching and learning; and responding new issues. The school curriculum also has to be flexible to incorporate emerging national priorities. The ICT curriculum for Ghana schools could be easy and insufficient for some schools in specific areas. The SBCD can add complex aspect to the central curriculum to meet learners' needs and level. In the last decade there has been several discussions about the potential for information and communication technologies (ICT) to transform teaching and learning in schools. In Ghana, a previous government with the support of RLG communications made heavy investments in ICT for use by teachers and students, but the purposes of these investments have not always been made explicit. ICT development in the school sector has sometimes paid insufficient attention to the pedagogical purposes for introducing the technology, or the supporting conditions and resources that might enable the technologies to contribute towards better teaching and learning experiences (Higgins, 2003). The evidence is that most teachers especially in the rural communities in Ghana have less knowledge of ICT and efficient professional development has not been given. This has rendered the investment useless. Simply providing ICT equipment to schools or teachers will not necessarily make a difference; what makes the difference is the way that this equipment and other resources are used (Higgins, 2003).

In 2010 in Amponsao D/A Junior high School. Parents and community elders had a fund raising to purchase three sets of computers for ICT practicals. Although I was the ICT teacher, with my in-depth practical knowledge, I was made the instructor for after school practice. At the end of the school year, we realized an increase in grades in school exams and Basic Education Certificate Examination (BECE) in ICT. However, the effect it has on other subject is not discussed here.

Society is dynamic and there are always new knowledge or issues that need to be learned by students. However, there can't be a continuous reformation of the central curriculum to meet these issues. In Ghana, one of the new social priorities now is for teenagers is to overcome Tramadol abuse. According to Modern Ghana News (https://www.modernghana.com/news/858741/ges-reveals-tramadol-abuse-responsible-for-student-rioting.html), The Ashanti Regional Directorate of the Ghana Education Service (GES) has revealed that there is widespread abuse of Tramadol in some Senior High Schools in the Region and that has resulted in violent clashes and disturbances in school. Since this abuse is a new situation, the central curriculum developers cannot have an emergent curriculum reform to cater for this issue. Therefore, an SBCD in conjunction with the central curriculum for Health and Drug Abuse would be the best tool in dealing with it.

teaching in Amposaso D/A school from September 2008 to July 2011. We realized that some people in the community contaminate water bodies to have a bountiful catch of fish. Teachers in connection with the district assembly member of the community took the mantle upon ourselves to discuss with students the negative effect of fishing with chemicals since the main source of drinking water was the rivers in the village. That led to the reduction of such practices.

\section{Recommendations}

Based on the above literature review and discussion of my observation, I strongly recommend SBCD into Ghana schools for more effective and efficient learning and teaching. It is clearly stated in literature and can be observed in my teaching experience and others', that the function of SBCD is quite obvious in the way that it drives students interest and motivation towards learning,

Also, as mentioned above, from the side of parents and community, SBCD serves their needs and interest and help address emergent issues of society in schools.

It is also recommended that teachers with specific skills be made to handle a respective aspect of the SBCD. Though it will mean putting on additional responsibilities.

\section{Conclusion}

I provide in this paper both a critical review of literature on the effects of SBCD and a discussion on its practical application in my teaching. SBC should be appropriately developed because of its influence and advantages in catering for students' needs. However, in developing SBC, teachers and schools will be faced with problems, such as collaboration among teachers and lack of professional skills in designing a whole curriculum. To recommend the policy in real life practice, it is highly suggested that schools ask for external supports and take their own pace in preparing for SBC according to the school's backgrounds and levels of their teachers and students. Also, a curriculum leader is suggested to have for each subject to help maintain coherence and conduct change.

Furthermore, schools and teachers should be well aware of the fact that both the central curriculum and SBC are dynamic. They should be prepared to modify the purposes, functions and approaches of their curricula from time to time according to the needs of their students and the society 


\section{REFERENCE}

Bezzina, M. (1991). Teachers' perceptions of their participation in school based curriculum development: A case study. Curriculum perspectives, 11 (2), 39-47.

Boomer, G., Lester, N., Onore, C., \& Cook, J. (1992). Negotiating the curriculum: educating for the 21 st century. London: The Falmer Press.

Brooker, R., \& Macdonald, D. (1999). Did we hear you?: Issues of student voice in a curriculum innovation. Journal of curriculum studies, 31 (1), 83-97.

Gruenewald, D. A. (2003). Foundations of place: A multidisciplinary framework for place-conscious education. American Educational Research Journal, 40 (3), 619-654.

Hannay, L. (1990). Canada: School-based curriculum deliberation. In C. Marsh, C. Day, L. Hannay, \& G. McCutcheon (Eds.), Reconceptualising school-based curriculum development (pp. 140- 172). London: The Falmer Press.

Higgins, S. (2003). Does ICT improve learning and teaching in schools? Newcastle University: A professional user review of UK research undertaken for the British Educational Research Association. Retrieved 26 July 2004, from http://www.bera.ac.uk/publications/pdfs/ICT\%20PUR\%20MB\%20r-f-p\%201Aug03.pdf

Marsh, C., Day, C., Hannay, L., \& McCutcheon, G. (1990). Reconceptualising school-based curriculum development. London: The Falmer Press

Marsh, C. (1990). Australia: establishing a Unit Curriculum for Years 8-10 at River Valley Senior High School. In C. Marsh, C. Day, L. Hannay, \& G. McCutcheon (Eds.), Reconceptualising school-based curriculum development (pp. 73-97). London: The Falmer Press

Sabar, N., Rudduck, J., \& Reid, W. (Eds.). (1987). Partnership and autonomy in school-based curriculum development. University of Sheffield: Division of Education

Marzano, Robert J (2003). Classroom management that works : research-based strategies for every teacher / Robert J. Marzano with Jana S. Marzano and Debra J. Pickering.

Modern Ghana News (https://www.modernghana.com/news/858741/ges-reveals-tramadol-abuse-responsible-forstudent-rioting.html)

Teacher support force (http://www.teacher-support-force.com/learning-context.html)

Rachel Bolstad, New Zealand Council for Educational Research rachel.bolstad@nzcer.org.nz Paper presented at the conference of the New Zealand Association of Research in Education (NZARE) Wellington, 24-26 November 2004

\section{Author:}

Stephen Nyame is currently a final year master's degree student of Curriculum and Instruction in Liaocheng University, Shandong China. He graduated from Foso College of Education, Ghana in the year 2008 and University of Education Winneba, Ghana in 2011 with Diploma in Basic Education and Bachelor of Education respectively. He has 12 years of teaching experience as classroom teacher and ESL teacher both in Ghana and China. 